\title{
Mouse models of colorectal cancer
}

\author{
Yunguang Tong ${ }^{1}$, Wancai Yang $^{2}$ and H. Phillip Koeffler ${ }^{1,3}$
}

\begin{abstract}
Colorectal cancer is one of the most common malignancies in the world. Many mouse models have been developed to evaluate features of colorectal cancer in humans. These can be grouped into genetically-engineered, chemically-induced, and inoculated models. However, none recapitulates all of the characteristics of human colorectal cancer. It is critical to use a specific mouse model to address a particular research question. Here, we review commonly used mouse models for human colorectal cancer.
\end{abstract}

Key words Colorectal cancer, mouse model, tumorigenesis, metastasis

Colorectal cancer is the third most common malignancy in the world. In the United States, colorectal cancer is the fourth most commonly diagnosed cancer and the second leading cause of cancer-related death ${ }^{[1]}$. The development of colorectal cancer is a process sequentially acquiring a number of genetic changes in normal epithelium, which enables precancerous cells to develop into an adenomatous polyp and progress into an invasive tumor (Figure 1) ${ }^{[2]}$. Inactivation of the adenomatous polyposis coli ( $A P C)$ gene and activation of the K-Ras proto-oncogene are two early events of colorectal tumorigenesis ${ }^{[3,4]}$. Germline mutation of the $A P C$ gene causes the familial adenomatous polyposis (FAP) syndrome. However, lesions exhibiting $K$-ras mutation without $A P C$ alteration result mostly in non-dysplastic lesions with limited potential to progress to carcinoma ${ }^{[5]}$. The next step in progression from adenoma to carcinoma is the loss of heterozygosity of chromosome 18q, which contains candidate tumor suppressor genes including SMAD2, SMAD4 and $D C C^{[6]}$. Mutation of $p 53$ on chromosome $17 q$ appears to be a late-stage event ${ }^{[2]}$. Some genetic changes do not affect the cell biology of the tumor but instead result in loss of genomic stability. As evidenced in patients with hereditary non-polyposis colorectal cancer (HNPCC),

\footnotetext{
Authors' Affiliations: 'Department of Medicine, Cedars-Sinai Medical Center, Los Angeles, CA 90048, USA; '2Department of Pathology, University of Illinois at Chicago, Chicago, IL 62269, USA; ${ }^{3}$ National Cancer Institute and Cancer Institute of Singapore, Singapore 119074, Singapore.

Corresponding Author: Yunguang Tong, Davis Building, Room 2015 8700 Beverly Blvd, Los Angeles, CA 90048, USA. Tel: +1-310-423-7669; Fax: +1-310-423-0221; Email: tongy@cshs.org. doi: $10.5732 /$ cjc.011.10041
}

loss of DNA mismatch repair (MMR) genes leads to microsatellite instability (MSI) and early-onset colorectal tumors ${ }^{[7,8]}$. In addition to MSI, colorectal cancer can develop chromosomal instability (CIN), which also occurs relatively early in tumor evolution ${ }^{[8-12]}$.

The laboratory mouse is one of the best model systems in biomedical research because of the availability of genetic/genomic information on individual murine lines and techniques to construct transgenic and knockout mice. Many mouse models for colorectal cancer have been generated and can be grouped as genetically-engineered, chemically-induced, and inoculated models. As none of these models recapitulate the process of colorectal cancer development in its entirety, it is important to use a specific model to address a particular scientific question. Here, we review commonly used mouse models for human colorectal cancer (Table 1).

\section{Mouse Models for Familial Adenoma- tous Polyposis (FAP)}

FAP is a hereditary disease with high penetrance that causes numerous polyps throughout the colon and rectum. Human $A P C$ gene is commonly deleted in many kindreds with FAP ${ }^{[13,14]}$. APC functions as a tumor suppressor to down-regulate the canonical WNT signaling pathway by binding to and promoting the degradation of $\beta$-catenin protein ${ }^{[15]}$. Loss of $A P C$ impairs $\beta$-catenin degradation ${ }^{[15,16]}$. The accumulated $\beta$-catenin moves to the nucleus, where it activates TCF/LEF transcription factors that transactivate Wnt-targeted genes $^{[17]}$. Activation of the canonical WNT pathway is a key event in colorectal tumorigenesis ${ }^{[18]}$. 


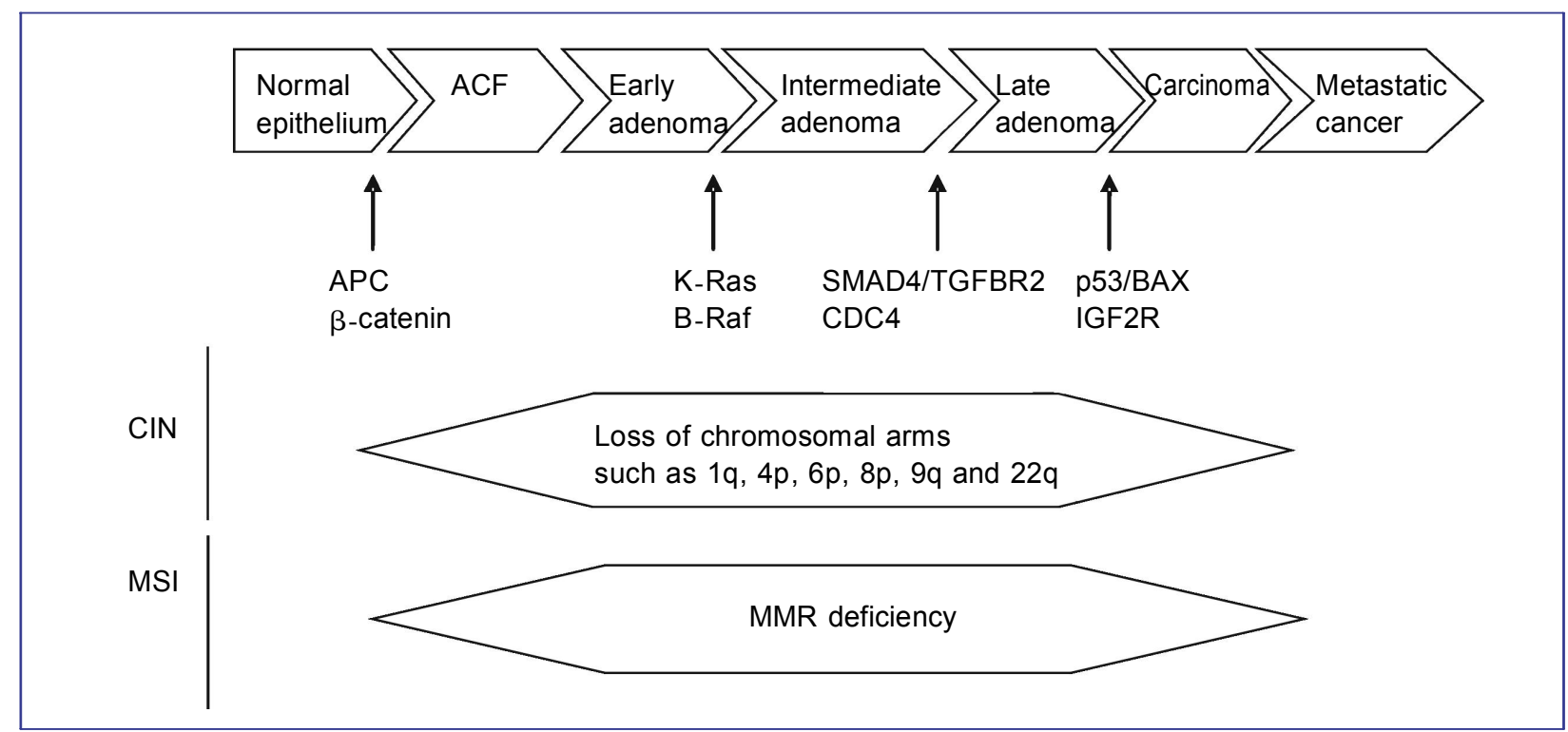

Figure 1. The development of colorectal cancer is a process sequentially acquiring a number of genetic changes in normal epithelium, which enables precancerous cells to develop into an adenomatous polyp and progress into an invasive tumor. Inactivation of the adenomatous polyposis coli $(A P C)$ gene and activation of $\beta$-catenin are early events of colorectal tumorigenesis. Activation of the $K$-Ras and $B$-Raf proto-oncogenes promotes tumorigenesis. The next step in progression from adenoma to carcinoma is the loss functions of candidate tumor suppressor genes including SMAD4/TGFBR2 and CDC4. Mutation of p53/ $B A X$ and IGF2R appears to be a late-stage event. Some genetic changes do not affect the cell biology of the tumor but instead result in loss of genomic stability. For example, colorectal cancer can develop chromosomal instability (CIN), which also occurs relatively early in tumor evolution. Loss of DNA mismatch repair (MMR) genes leads to microsatellite instability (MSI) and early-onset colorectal tumors. ACF, aberrant crypt foci.

\section{Table 1. Mouse models for human colorectal cancer}

\begin{tabular}{|c|c|c|}
\hline Human disease & Mouse model & Advantages and disadvantages \\
\hline FAP & $\begin{array}{l}\text { Apc mutants or } \beta \text {-catenin transgenic } \\
\text { mice }\end{array}$ & $\begin{array}{l}\text { Mimic APC mutation in human. However, most tumors located in the small } \\
\text { intestine. Tumors are not metastatic. }\end{array}$ \\
\hline HNPCC & $M s h 2^{-1-}, M_{s h 6^{-1-}, \text { and } M I h 1^{-1-} \text { mice }}$ & $\begin{array}{l}\text { Mimic MMR deficiency in human. However, MMR-deficient mice develop tumors } \\
\text { in other organs. The colonic tumors are not metastatic. }\end{array}$ \\
\hline \multirow[t]{3}{*}{$\begin{array}{l}\text { Inflammation-related } \\
\text { colorectal cancer }\end{array}$} & DSS-induced mouse models & $\begin{array}{l}\text { Easy and reproducible. Tumor incidence is low. AOM/DSS combination produces } \\
\text { more tumors at earlier time point. }\end{array}$ \\
\hline & 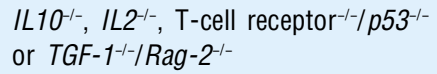 & Tumor incidence is low. Requires the involvement of enteric microflora. \\
\hline & $\mathrm{Muc2}^{-1-}$ & $\begin{array}{l}\text { High incidence of colon and rectal tumors. Early development of rectal prolapse } \\
\text { reduces life span. }\end{array}$ \\
\hline \multirow[t]{2}{*}{$\begin{array}{l}\text { Sporadic colorectal } \\
\text { cancer }\end{array}$} & Carcinogen-induced mouse model & $\begin{array}{l}\text { Easy and reproducible. DMH/AOM/MAM have relatively high colorectal tumor } \\
\text { incidence. IQ, PhIP, DMAB, MNNG or MNU target multiple organs and exhibit a } \\
\text { low tumor incidence. The tumors are not metastatic. }\end{array}$ \\
\hline & $\begin{array}{l}\text { Cre adenovirus-mediated Apc } \\
\text { inactivation }\end{array}$ & $\begin{array}{l}\text { Require surgical procedures. Results are reproducible. Develop metastasis in } \\
\sim 20 \% \text { of animals. }\end{array}$ \\
\hline \multirow[t]{4}{*}{$\begin{array}{l}\text { Metastatic colorectal } \\
\text { cancer }\end{array}$} & Orthotopic inoculation model & $\begin{array}{l}\text { Mimics colon tumor invasion, vascular spread, and metastasis to distal organ. } \\
\text { Metastasis rates depend on cell lines and rodent strains. }\end{array}$ \\
\hline & Intrasplenic inoculation model & $\begin{array}{l}\text { Reproducible and mimics vascular spread of colorectal cancer. Metastasis rates } \\
\text { depend on cell lines and rodent strains. }\end{array}$ \\
\hline & Intraportal inoculation model & $\begin{array}{l}\text { Mimics vascular spread of colorectal cancer metastasis and theoretically limits } \\
\text { tumor growth predominantly to the liver. Metastasis rates depend on cell lines } \\
\text { and rodent strains. }\end{array}$ \\
\hline & Intrahepatic inoculation model & $\begin{array}{l}\text { Model is reproducible but does not mimic the generally accepted hypothesis of } \\
\text { hematogenous spread of colorectal cancer. }\end{array}$ \\
\hline
\end{tabular}

FAP, familial adenomatous polyposis; HNPCC, hereditary nonpolyposis colorectal cancer; MMR, mismatch repair; DSS, dextran sulfate sodium; MAM, methylazoxymethanol; DMH, 1,2-dimethylhydrazine; AOM, azoxymethane; PhIP, 2-amino-1-methyl-6-phenylimidazo[4,5-b]pyridine; IQ, 2-amino-33-methylimidazo [4,5-f] quinoline; DMAB, 3,2'-dimethyl-4-aminobiphenyl; MNU, methylnitrosourea; MNNG, N-methyl-N'-nitro-N-nitrosoguanidine. 
The first murine $A p c$ gene mutation, named $A p c^{\mathrm{Min}}$ (multiple intestinal neoplasia), was identified in a colony of mice following random mutagenesis ${ }^{[19]}$. This mutation is a truncating mutation at codon 850 of the Apc gene ${ }^{[20]}$. Homozygote $A p c^{\mathrm{Min}}$ mice are embryonic lethal, whereas heterozygote $A p C^{\text {Min }}$ mice on a C57BL/6 background typically develop $\sim 30$ polyps, the majority of which occur in the small intestine ${ }^{[19,21]}$. Using homologous recombination in embryonic stem cells, several additional Apc mutants have been constructed: $A p c^{\Delta 716}$, which contains a

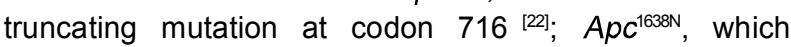
contains a neomycin insertion in exon 15 that produces a truncating mutation at codon 1638; $A p c^{1638 T}$, which contains a hygromycin insertion in exon 15 resulting in a

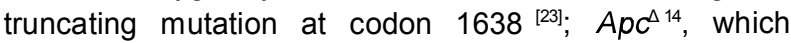

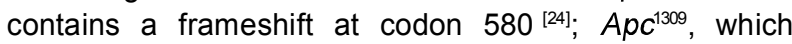

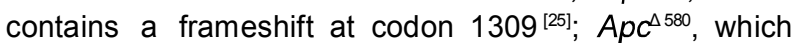
contains a frameshift at codon 580 and a truncation at codon $605^{[26]}$; and $A p c^{\triangle 474}$, which contains a frameshit at codon $474^{[27]}$. The polyp adenomas of these Apc-mutant mice are histologically indistinguishable from each other, but the number of polyps developed is very different, even in the same C57BL/6J background. The $A p c^{\Delta 716}$ mouse develops $\sim 300$ polyps, Apc ${ }^{1638 \mathrm{~N}}$ mouse develops $\sim 3, A p c^{\triangle 14}$ mouse develops $\sim 65, A p c^{1309}$ mouse develops $\sim 35$, $A p c^{\triangle 580}$ mouse develops $\sim 120$, and $A p c^{\triangle 474}$ mouse develops $\sim 30^{[16]}$. Similar to $\mathrm{Apc}^{\mathrm{Min}}$ mice, these mutant mice primarily develop polyps in the small intestine. Comparing to $\mathrm{Apc}^{\mathrm{Min}}$ mice, despite the significant increase in polyps in the small intestine, there is no increase in polyps in the colon in mice with some Apc mutants, such as $A p c^{\Delta 716}$. In addition to early onset of gastrointestinal tumors, $A p c^{\mathrm{Min}}$ mice show progressive loss of immature and mature thymocytes from $\sim 80$ days of age, with complete regression of the thymus by 120 days ${ }^{[28]}$. Also, splenic natural killer cells, immature $B$ cells, and B progenitor cells are depleted in the bone marrow. $A p c^{\mathrm{Min}}$ mice have perturbations in ammonia metabolism in the liver ${ }^{[29]}$. Circulating interferon-6 (IL-6) increases 10-fold, causing severe cachexia as exemplified by loss of muscle weight and fat tissues ${ }^{[30]}$. Due to these complications, most Apc-mutant mice die young (4 to 5 months).

Additional mouse models have been developed to test genes affecting tumorigenesis in mice with $A p c$ mutations. K-Ras mutations are very common in colorectal cancers. Constitutively active mutant K-ras $\left(K-\right.$ ras $^{G 12 D}$ ) promotes colorectal tumor development in Apc-heterozygous mice. Adenocarcinomas expressing $K-\operatorname{Ras}^{G 12 D}$ invariably exhibit uniform high-grade dysplasia throughout the gut, but this does not occur in mice expressing wild-type $K$-ras ${ }^{[31]}$. Mice that are homozygous for the Apc conditional knockout (CKO) allele and heterozygous for a latent activated allele of $K$-Ras

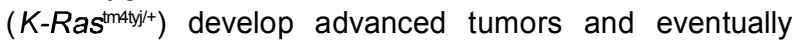

form liver metastasis ${ }^{[32]}$. COX-2 is expressed in early stage of polyp formation ${ }^{[33]}$. Knockout of COX-2 gene (Ptgs2) in $A p c^{\Delta 716}$ mice dramatically reduces the number and size of polyps in these compound mutant mice ${ }^{[33,34]}$. Mutation in the $C d x 2$ gene in $A p c^{\triangle 116}$ mice results in most polyps occurring in the colon ${ }^{[35]}$. Cdx2-mutant mice exhibit an increased frequency of loss of heterozygosity (LOH) of the Apc gene due to chromosomal instability, which may result from activation of the mTOR pathway and acceleration of the $G_{1}$ to $S$ phase transition in the cell cycle. Introduction of a Bub $b^{\mathrm{R} 1+/}$ mutation into $A p c^{\mathrm{Min}}$ mice causes a 10 -fold increase in the number of colonic tumors compared to $A p c^{\mathrm{Min}}$ mice ${ }^{[36]}$. Both $C d x 2-$ and BubR1-mutant mice exhibit a higher rate of genomic instability ${ }^{[35,36]}$, making them good models for prevention and treatment of colon cancers with chromosomal instability. Introduction of Smad4 mutation into $A p c^{4716}$ polyposis mice results in locally invasive malignant adenocarcinomas without metastasis ${ }^{[37}$. The histopathologic manifestations are similar to human right-sided colon cancer, which is associated with mutations in the type II receptor of transforming growth factor (TGF)- $\beta$. Consistently, homozygous disruption of the type II receptor of the TGF- $\beta$ gene (Tgfbr2) in $A p c^{1638 \mathrm{~N}}$ mice causes malignant transformation of the intestinal adenomas induced by $A p c$ mutation ${ }^{[38]}$. Inactivation of cyclin-dependent kinase inhibitors (CDKI) p21 and p27 significantly enhances intestinal tumorigenesis in the $A p c^{1638 \mathrm{~N}}$ mice ${ }^{[39,40]}$. These $A p c^{1638 \mathrm{~N}}$ compound mouse models highlight the importance of $p 21$, but not $p 27$, in colon cancer prevention by non-steroidal antiinflammatory drugs (NSAID) ${ }^{[39,40]}$. $A p c^{\mathrm{Min}}$ mice with heterozygous disruption of Pten develop invasive carcinomas that are large, making this a good animal model for studying persistent activation of the phosphatidylinositol 3-kinase/Akt pathway in colorectal cancer $^{[41]}$. Recently, mutation of Prox 1 in $A p c^{\text {Min }}$ mice has been reported to promote progression of colon adenoma to cancer ${ }^{[42]}$, suggesting that this model could be useful to study tumor progression.

\section{Hereditary Non-polyposis Colorectal Cancer (HNPCC) Models}

HNPCC (Lynch syndrome) is one of the most prevalent malignancies in the western world and accounts for about $5 \%$ of all colorectal cancers. Patients with HNPCC develop early-onset tumors in the colon and rectum, and a subset of patients also develop tumors in the stomach, small intestine, ovaries, and endometrium ${ }^{[43]}$. Patients with HNPCC carry a mutant allele of the DNA MMR genes, such as MLH1, MSH2, and MSH6 ${ }^{[446]}$. Upon mutation of the wild-type allele by somatic events, the cells become MMR-deficient, and their genomic DNA 
displays increased rates of replication errors at short repeat sequences, which is termed microsatellite instability $(\mathrm{MSI})^{[47-49]}$.

Heterozygous Msh2, Msh6, and Mlh1 knockout mice do not develop early-onset tumors, but homozygous Msh2, Msh6, and Mlh1 knockout mice are cancer-prone, developing tumors in multiple organs including the gastrointestinal tract. These homozygous knockout mice die prematurely due to aggressive lymphomas, which are very similar to patients with biallelic mismatch repair mutations ${ }^{[50,51]}$. These phenotypes in humans and mice suggest that the basic mechanisms of DNA repair and tumor suppression are conserved.

Msh2 ${ }^{-}$murine cells are unable to repair single-base mismatches and 1- to 4-base insertion/deletion loops (IDLs). The loss of MMR in these mice causes a severe reduction in survival and a strong cancer predisposition phenotype ${ }^{[52,53]}$. Most $M s h 2^{-/}$mice die from T-cell lymphomas by 6 to 8 months, and those that survive often develop small intestinal adenomas and invasive adenocarcinomas. Similar to tumors in patients with HNPCC, the tumors in Msh2-- mice have high $\mathrm{MSI}^{[53]}$. To avoid early death caused by tumorigenesis in other organs, conditional Msh2 knockout mice, in which intestine-specific gene inactivation is permitted, have been generated using either Villin-Cre or Cdx2-NLS-Cre. These mice develop tumors that highly mimic tumors developed by patients with Lynch syndrome, which make the mice useful preclinical models ${ }^{[54]}$.

Msh6-deficient mice survive longer (up to 18 months) and develop tumors at an older age than Msh2-deficient mice ${ }^{[55]}$. Msh6-deficient cells exhibit dysfunctional repair of base substitution mutations and single-base IDLs. Because $\mathrm{Msh}^{\prime-}$ mice predominantly have base substitution mutations rather than frame shift mutations, tumors in these mice do not display the MSI phenotype that is a characteristic of HNPCC. In parallel, individuals with germ-line $\mathrm{MSH} 6$ mutations frequently have atypical HNPCC characterized by cancer onset at more than 60 years old and a variable MSI phenotype ${ }^{[56]}$. Moreover, Msh6'- mice also develop endometrial cancers, which is consistent with a significant number of patients with $\mathrm{MSH} 6$ mutations ${ }^{[57]}$.

$M / h 1^{-1-}$ mice exhibit complete MMR deficiency, have a shortened life span (up to 12 months) and a strong cancer predisposition, similar to Msh2-deficient mice. The tumor spectrum of $\mathrm{Mlh}^{-1-}$ mice includes T-cell lymphomas, intestinal adenomas and adenocarcinomas, and skin tumors, which are high $\mathrm{MSI}^{[58-60]}$.

A significant number of MSI-positive human colorectal cancers carry somatic mutations in the $A P C$ gene, indicating that loss of APC function is critical for tumor initiation and/or progression in MMR-deficient tumors. Mice that have homozygous mutations of Msh2, Msh6, Mlh1, or Pms2 and heterozygous germ-line mutations of Apc develop tumors almost exclusively in the intestinal tract ${ }^{[61-64]}$. Specifically, in Apc-mutant mice, functional loss of Msh2 or Mlh1 dramatically increases intestinal tumors ${ }^{[61,62]}$, while functional loss of Msh6 or Pms2 moderately increases intestinal tumors ${ }^{[63,64]}$. Functional loss of Msh3, on the other hand, does not increase the tumor load ${ }^{[64]}$. The incidence of tumors correlates with the severity of the MMR defects in MMR knockout mice.

\section{Chemically Induced Colorectal Cancer Models}

Carcinogen induced colorectal cancer in mice is rapid and reproducible, and recapitulates the adenoma-toadenocarcinoma sequence that occurs in humans. The availability of genetically-engineered or specific inbred mice add further value to these models. Commonly used carcinogens include the following: 1) methylazoxymethanol (MAM), 1,2-dimethylhydrazine $(\mathrm{DMH})$, and azoxymethane (AOM); 2) heterocyclic amines (HCAs), such as 2-amino-1-methyl-6phenylimidazo [4,5-b]pyridine (PhIP) and 2-amino-33methylimidazo $[4,5-f]$ quinoline $(\mathrm{IQ})$; 3) aromatic amines, such as 3,2' -dimethyl-4-aminobiphenyl (DMAB); and 4) alkylnitrosamide compounds, such as methylnitrosourea (MNU) and N-methyl-N'-nitro-N-nitrosoguanidine (MNNG).

MAM was first identified in Cycad flour and found to be carcinogenic in both humans and rats ${ }^{[6,66]}$. $\mathrm{DMH}$ and AOM (DMH metabolite) are MAM precursors, which require metabolic activation to form DNA-reactive products ${ }^{[67-69]}$. The reactive metabolite, MAM, readily yields a methyl diazonium ion that can alkylate macromolecules in the liver and colon ${ }^{[67,70,71]}$, including guanine (by adding methyl groups at either the 06 or N7 position to form O6-methyl-deoxyguanosine or N7-methyl-deoxyguanosine). Repetitive treatment with $\mathrm{DMH}$ produces colon tumors in rodents that exhibit many of the pathologic features associated with the human disease ${ }^{[72-74]}$; thus, it represents a reliable, reproducible experimental system for studying sporadic (non-familial) colorectal cancer. AOM is advantageous over $\mathrm{DMH}$ because of its stronger potency and greater stability during administration ${ }^{[7]}$. As in human populations, inbred murine strains differ in their sensitivity to colon carcinogens. SWR/J and A/J mice are sensitive to AOM and develop up to 20 tumors in the distal colon, whereas $\mathrm{AKR} / \mathrm{J}$ mice are resistant and rarely develop tumors ${ }^{[76,77]}$. Also, FVB/N and Balb/c murine strains that are commonly used for constructing gene knockout and transgenic animals, develop approximately four tumors and one tumor per mouse, respectively, upon treatment with AOM ${ }^{[76,77]}$. The 129SvJ, C57BI/6J, AKR/J, and $\mathrm{DBA} / 2 \mathrm{~J}$ mice are relatively resistant to $\mathrm{AOM}$ and $\mathrm{DMH}^{[77]}$. In contrast, $\mathrm{DMH}$ induces colon cancer with moderate 
success in Balb/cHeA and SWR/J mice and with high success in $A / J, P / J, S T S / A$, and ICR/Ha mice ${ }^{[78-82]}$. Interestingly, the morphology of AOM-induced dysplasia appears nearly identical between these mouse strains even though they exhibit a difference in their sensitivity to colon cancer development ${ }^{[83]}$. The reason for this strain-specific difference in carcinogen sensitivity is not clear, but data suggest involvement of subsequent carcinogenic steps such as tumor promotion rather than the result of differences in carcinogen metabolism ${ }^{[84]}$.

HCAs, including IQ and PhIP, are mutagens usually formed upon broiling fish and meat ${ }^{[85-87]}$. The precursors of IQ-type HCAs are creatinine, amino acids, and sugars in fish and meat ${ }^{[87]}$. IQ requires metabolic activation by liver microsomes for conversion to its ultimate carcinogen, and subsequently form high levels of DNA adducts in a number of organs ${ }^{[88-90]}$. PhIP (4 weekly intraperitoneal injection at $50 \mathrm{mg} / \mathrm{kg}$ body weight) increases the number of small tumors and cystic crypts in the small/large intestines in $A p c^{\mathrm{Mn}}$ mice, but only induces a few aberrant crypt foci (ACF) in the large intestines in wild-type mice ${ }^{[91]}$. Both IQ and PhIP induce intestinal tumors in $A p C^{\mathrm{Mn}}$ mice associated with inactivation of the wild-type $A p c$ allele, either by causing LOH or truncation mutations ${ }^{[92]}$. Rats who receive either $\mathrm{IQ}$ or PhIP have a high frequency of colon, mammary gland, and prostate cancers ${ }^{[33-96]}$. However, the incidence of colon tumor is low, ranging from $5 \%$ to $28 \%$ when these agents are administered in the diet for up to 52 weeks ${ }^{[97]}$. Short-term intermittent feeding of $400 \mathrm{mg} / \mathrm{kg}$ $\mathrm{PhIP}$ in combination with a high-fat diet results in accelerated tumor formation ${ }^{[93]}$. Thus, the HCA-induced colon cancer model is useful to investigate the chemopreventive activity of potential agents against colon carcinogenesis.

DMAB, an aromatic amine, was first reported to be

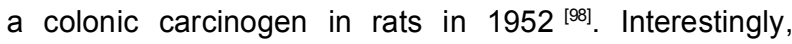
injections of DMAB to male F344 rats (weekly subcutaneous injection at $50 \mathrm{mg} / \mathrm{kg}$ body weight) induced multiple colon tumors in $27 \%$ and $75 \%$ of rats fed either a low-fat or high-fat diet, respectively ${ }^{[99,100]}$. DMAB induced both adenomas and adenocarcinomas, with a multiplicity of 1.2 to 2.7 tumors per tumor-bearing rat. $D M A B$ is less potent in rodent models than $\mathrm{DMH}$ or $A O M$. It is less organ-specific and induces neoplasms in mammary and salivary glands, ear ducts, skin, forestomach, and urinary bladder ${ }^{[73,101,102]}$.

MNNG and MNU are direct alkylating agents that do not require metabolic activation. Intrarectal instillation of MNU or MNNG in rodents induces colorectal tumors ${ }^{[103-105]}$ that are predominantly sessile or polypoid lesions. For example, intrarectal administration of MNNG (1 to 3 $\mathrm{mg} /$ week) for 20 weeks induced colon tumors at the injection site in all male $\mathrm{F} 344$ rats $(57 \%$ adenomas, $43 \%$ adenocarcinomas ) ${ }^{[104,105]}$. Most of the resultant adenocarcinomas were well differentiated with infiltration into the submucosa, but a minority was poorly differentiated and showed mucinous cancer cells infiltrating into the submucosa. As no biochemical activation is required for MNU or MNNG action, these carcinogens are ideal for studying the modifying effects of xenobiotics in colorectal tumorigenesis without involving carcinogen metabolism ${ }^{[106]}$.

Taken together, all of these carcinogens cause mutations and deletions in a spectrum of genes that are known to be involved in human colon cancer tumorigenesis. K-Ras activating mutations ( $G$ to $A$ ) were found in $66 \%$ of $\mathrm{DMH}$-induced colon carcinomas ${ }^{[107]}$ and $33 \%$ of MNU-generated carcinomas ${ }^{[108]}$. p53 mutations are frequent in MNU-induced rat colon tumors. In contrast, K-Ras but not $A p c$ and p53 mutations are frequently observed in AOM-induced lesions [109-111]. Apc mutations are frequent ${ }^{[112,113]}$ but $K$-Ras mutations are rare in PhIP-induced colon tumors ${ }^{[14]}$. In carcinogen-induced rodent colon tumors not having Apc mutations, $\beta$-catenin mutations can occur ${ }^{[115-117]}$, indicating the importance of the $\mathrm{Wnt} / \mathrm{Apc} / \beta$-catenin signaling pathway in chemicallyinduced rodent colon carcinogenesis.

\section{Inflammation-Related Colorectal Cancer Models}

Inflammation plays important roles in the development of colorectal cancer; the risk increases with the extent and duration of inflammation. Colorectal cancer is one of the most serious complications associated with long-standing inflammatory bowel disease (IBD). Several mouse models for inflammation-related colorectal cancer have been developed, including dextran sodium sulphate (DSS) -induced colitis models and genetically engineered models.

\section{DSS-induced colitis model}

The most commonly used colitis mouse model uses DSS [118]. Colorectal cancer development following DSS-induced inflammation suggests that chronic inflammation in IBD plays a critical role in epithelial malignant neoplasia of the colon and rectum ${ }^{[199}$. This model is DSS dose-dependent and typically requires a relatively long exposure period and low repeated cycles of DSS administration ${ }^{[120]}$. The incidence and/or multiplicity of DSS-induced colorectal tumors are relatively low ${ }^{[121]}$. To promote tumorigenesis, mice are often treated with AOM and DSS and then develop tumors after a relatively short-term exposure ${ }^{[122]}$. Different strains of mice exhibit distinct susceptibilities to AOM/DSS-induced colon carcinogenesis ${ }^{[120]}$. For example, nearly $100 \%$ Balb/c mice developed colonic 
adenocarcinoma, with a multiplicity of $7.7 \pm 4.3$; in contrast, only $50 \%$ of $\mathrm{C} 57 \mathrm{BL} / 6 \mathrm{~N}$ mice formed tumors, with a multiplicity of $1.0 \pm 1.2$; and even less robustly, both $\mathrm{C} 3 \mathrm{H} / \mathrm{HeN}$ and $\mathrm{DBA} / 2 \mathrm{~N}$ mice developed only a few colonic adenomas ${ }^{[120]}$. In addition, DSS-treated $A p C^{\mathrm{Min}}$ mice also develop more colon tumor than vehicle control-treated ones ${ }^{[123]}$.

In the AOM/DSS model, dysplastic lesions are initially formed in the colonic mucosa. Both dysplasia and neoplasia stain positive for $\beta$-catenin, COX-2, and inducible nitric oxide synthase but not $p 53$. Mutations of the $\beta$-catenin gene occur in $80 \%$ to $100 \%$ of $A O M$-induced or $\mathrm{DMH} / \mathrm{DSS}$-induced colonic adenocarcinomas ${ }^{[123,124]}$. Mice developing colonic adenocarcinomas often have mutations of the $\beta$-catenin gene at codons 32 to 34 if the mice receive $A O M / D S S^{[123]}$ or at codons 33,37 , and 41 if the mice receive $A O M{ }^{[17]}$. Collectively, these results suggest that mutations at codons 33 and 34 might be caused by AOM exposure, whereas mutations at codon 32 may result from DSS exposure ${ }^{[17,125]}$. Gene expression of Wnt inhibitory factor 1 (Wif1), plasminogen activator (Plat), myelocytomatosis oncogene $(M y c)$, and phospholipase A2 group IIA (platelets and synovial fluid) (Plscr2) are up-regulated, and the inflammation-related gene, peroxisome proliferator-activated receptor- $\gamma$ (Ppary), PPAR-binding protein (Pparbp), and Tgfb3 are down-regulated at 5 to 10 weeks of AOM/DSS exposure ${ }^{[126]}$. Similar to the AOM/DSS model, mice receiving the colon carcinogens (PhIP and $\mathrm{DMH}$ ) followed by DSS treatment have a higher incidence of tumors $^{[124,127]}$.

\section{Genetically engineered IBD mouse models}

The immune system plays an important role in the etiology of colonic inflammation. Disruption of the immune response to antigenic stimuli is strongly associated with IBD and IBD-related colorectal cancer. IL-2- and IL-10-defective mice develop IBD similar to humans. The level of inflammation in IL-10-defective mice correlates with the incidence of colorectal adenocarcinomas $^{[128]}$. The combination of IL-2 deficiency with 2-microglobulin deficiency in mice causes colonic inflammation, and some of these mice develop adenocarcinoma of the proximal colon ${ }^{[129,130]}$. Notably, IL-2- and IL-10-defective mice, as well as either T-cell receptor/p53- or TGF-1/Rag-2-deficient mice, do not develop chronic inflammation or intestinal tumors when maintained under germ-free conditions, suggesting that the enteric microflora plays an important role in the development of IBD and IBD-associated cancers in these mice ${ }^{[131-134]}$.

Activation of nuclear factor- $\mathrm{B} \quad(\mathrm{NF}-\kappa \mathrm{B})$ and correlated pro-inflammatory cytokines and adhesion molecules are required for inflammation-related intestinal neoplasia ${ }^{[135,136]}$. Studies with Nod2 (Card15) knockout mice indicate Nod2 is a positive regulator of NF- $\mathrm{KB}$ and IL-1 $\beta$ secretion and increases susceptibility to inflammation induced by bacteria in the intestine ${ }^{[137,138]}$. Blocking NF- $\mathrm{KB}$ signaling reduces colonic inflammation and carcinogenesis in the AOM/DSS model ${ }^{[135,137-140]}$. Chronic colitis appears to require activation of the Toll-like receptor-4 (TLR4). Genetically, TIr4-deficient mice have decreased levels of Cox-2 and Pge2 expression, as well as activation of the epidermal growth factor receptor signaling pathway. These mice are also more resistant than wild-type mice to the development of colitis ${ }^{[139]}$. Inhibition of TLR4 or tumor necrosis factor- $\alpha$ signaling could be useful in treating IBD-associated dysplastic colonic tissue.

Another genetically engineered colorectal mouse model is the Muc2 $2^{-}$mouse. Muc2 encodes the major gastrointestinal mucin, which forms an insoluble mucous barrier that protects the intestinal lumen ${ }^{[141-143]}$. Targeted inactivation of Muc2 causes tumor formation throughout the intestinal tract, including the colon and rectum [141]. Muc2 ${ }^{\text {- }}$ mice have a chronic intestinal inflammation associated with up-regulation of Cox-2 and cytokines, increased cell migration and proliferation, and decreased apoptosis. However, unlike other mouse colon cancer models, such as $A p c^{\mathrm{Min}}$ and $A p c^{1638+/-}$ mice ${ }^{[19144]}$, the $\beta$-catenin pathway is not involved in tumorigenesis [141,145,146]. Inactivation of $p 21$ in $\mathrm{Muc2}^{--}$mice significantly increases tumorigenesis, possibly through down-regulating p27 and up-regulating $c-M y c{ }^{[40]}$. Muc2 ${ }^{-/}$mice possessing an Apc mutation have significantly increased colorectal carcinogenesis, perhaps through an interaction between $\beta$-catenin and chronic inflammation ${ }^{[146]}$.

\section{Metastatic Colorectal Cancer Models}

Almost a third of patients with colorectal cancer have metastatic disease at the time of diagnosis. Moreover, half of the patients who are diagnosed with and undergo resection for early-stage disease subsequently develop metastasis. Metastatic colorectal cancer is difficult to treat and, ultimately, nearly all patients die of their disease ${ }^{[147]}$. Mice that are genetically-engineered or carcinogen-induced to develop colon cancer rarely develop metastasis. In contrast, models using transplant colorectal cancers can exhibit high rates of metastasis and recapitulate some of the desired characteristics.

Orthotopic implantation is defined as the inoculation of tumor cells/tissue in the intestine, for example, cecum or rectum ${ }^{[148]}$. This method mimics colon tumor invasion, vascular spread, and metastasis to distal organs. The metastasis rates depend on cell type, implantation site, and rodent strain. For example, colon cancer MCA-38 
and RCN-9 cells produced liver metastasis in $40 \%$ to $65 \%$ of mice 8 weeks after intramural injection into the cecal wall of $\mathrm{C} 57 \mathrm{BL} / 6 \mathrm{~J}$ mice ${ }^{[149,150]}$. Liver metastases have also occurred by inoculating human colon cancer tissues orthotopically in nude mice ${ }^{[151,152]}$. The histological features of the transplanted tumors may help determine the success of liver metastasis formation [152]. However, neither mouse colon carcinoma CT-26 cells (in Balb/c), MCA-38 cells (in C57BL/6J), nor DHD/K12-PROb cells (in BD-IX rats) developed liver metastasis when injected into the wall of the rectum or cecum ${ }^{[153,154]}$. Orthotopic implantation of colon cancer cells into mice has also resulted in metastasis to lymph nodes and other sites. Three human colon cancer cell lines (HCT-116, SW-620, and DLD-1) orthotopically injected into the cecal wall of nude mice showed varying degrees of mesenteric and retroperitoneal lymphatic invasion, hematogenous dissemination to the liver and lungs, as well as peritoneal carcinomatosis $(29 \% \text { to } 100 \%)^{[155]}$. Another series of experiments placing human colon cancer in the cecal wall of immunodeficient mice showed that lymph node metastases occurred most frequently using HCC2998 and HT29 cells. SW620 cells gave rise to multiple small (2 to $3 \mathrm{~mm}$ ) metastatic hepatic nodules, and CaCo2, WiDr, and Co205 cells had very low rates of metastasis ${ }^{[156]}$.

Intrasplenic injection of tumor cells mimics the vascular spread of colorectal cancer. This procedure is relatively easy and consistently induces liver metastases. Mortality caused by either splenic injection or local tumor growth can be controlled by splenectomy following injection ${ }^{[157]}$. Paradoxically, in one series of experiments, liver metastasis occurred more frequently when moderate to well differentiated cells (CX-1, HT-29, CCL188, and CCL235) but not poorly differentiated cells (MIP-101, Clone A, CCL222, and CCL231) were intrasplenically injected ${ }^{[158]}$. In another series of intrasplenic injection-induced liver metastasis experiments, many of the human colon cancer cells (metastatic capability: COLO320DM and HCT116 $>$ HT-29, WiDr and LoVo > LS174T) spread to the liver, with a frequency ranging from $50 \%$ to $100 \%$ of mice. CaCo2, COLO201, LS123, SW48, and SW1417 cells showed no metastasis after $1 \times 10^{4}$ cells were injected ${ }^{[159]}$. Rodent colorectal cancer cells also exhibit different metastatic capabilities. Mouse colon cancer MCA-38 cells and mucinous colon adenocarcinoma WB-2054-M4 cells efficiently developed liver metastases in C57BL/6J mice and Wistar/Furth $\times$ Brown-Norwegian hybrid rats, respectively, when injected intrasplenically ${ }^{[160,161]}$. However, K12-TR cells failed to develop liver metastases after injection into the spleens of BD-1X rats, as well as nude rats and mice ${ }^{[162]}$.

Intraportal injection of tumor cells mimics the vascular spread of colorectal cancer metastasis and theoretically limits tumor growth to the liver. Current data show that this procedure reproducibly results in liver metastases in almost all animals. Partial hepatic ischemia before injection of tumor cells further increases the number of hepatic metastases, likely due to up-regulation of expression of adhesion molecules induced during hepatic ischemia ${ }^{[163,164]}$. WB-2054-M cells, originally from a lung metastasis, yielded liver metastases in $50 \%$ of Wistar/Furth $\times$ Brown-Norwegian hybrid rats ${ }^{[165]}$. Colon cancer CC531, LDLX40, DHDK12/TR, and LMCR cells developed liver metastasis in all Wistar, WAG/Rij, and BDIX rats when injected into the portal vein ${ }^{[166-172]}$.

Intrahepatic (subcapsular or intraparenchymal) implantation of tumor cells is a widely used method to create liver metastases. The model is reproducible and has acceptable complication rates. However, as this method does not mimic the generally accepted hypothesis of hematogenous spread of colorectal cancer, these tumors might not reflect the human situation, and, therefore, may behave aberrantly to therapeutic interventions. Despite this disadvantage, such induction of tumors has been used by many investigators to study local therapy of metastases. For example, CC531 as well as $\mathrm{N}$-methyl-N-nitrosoguanidine (NNG) induced colon adenocarcinoma cells develop tumors in all animals in several weeks when injected into the liver of WAG/Rij or Wistar rats respectively [173-178], and DHDK12/TR cells develop tumors in BD-IX rats in all animals 6 weeks after injection ${ }^{[179]}$. Intrahepatic implantation of tumor fragments of human colon cancer, derived from a liver metastasis of a patient, resulted in $100 \%$ liver metastases after only 10 days $^{[180]}$.

\section{Conclusions and Future Direction}

A variety of mouse models of human colorectal cancer have been developed, and each imitates, in part, human colon carcinogenesis. These models allow rapid and repeated interrogation of hypotheses, and each produces a method to test various therapeutic modalities that would not be possible in humans. Genetically-engineered mice models are useful for studying the importance of specific genomic alterations in the development and progression of colorectal cancer and their sensitivity to various therapies. The chemically-induced mouse models mimic human sporadic colorectal cancer and are often used to study dietary influences on carcinogenesis. The inoculated colorectal cancer models recapitulate some features of colorectal cancer metastasis and are useful models for anti-metastatic drug evaluation. Even though each mouse model recapitulates an aspect of human colorectal cancer, the power of these models to predict 
clinical efficacy of treatments may be limited. Genetic and chemical mouse models may not reproduce the complexity of the human disease, and injection of human and murine colon cancer cell lines might be hampered because the long-term cultured cell line might have accumulated features that no longer reflect the characteristics of freshly isolated tumor cells. Also, differences in mouse size and physiology, as well as variations in colon cancer that develops in mice and humans may also lead to translational limitations. Nevertheless, each system has the exciting and robust capacity to model human colon cancer, facilitating a

\section{References}

[1] Jemal A, Siegel R, Xu J, et al. Cancer statistics, 2010 [J]. CA Cancer J Clin, 2010,60(5):277-300.

[2] Fearon ER, Vogelstein B. A genetic model for colorectal tumorigenesis [J]. Cell, 1990,61(5):759-767.

[3] Nagase H, Nakamura $\mathrm{Y}$. Mutations of the apc (adenomatous polyposis coli) gene [J]. Hum Mutat, 1993,2(6):425-434.

[4] Forrester K, Almoguera C, Han K, et al. Detection of high incidence of $\mathrm{k}$-ras oncogenes during human colon tumorigenesis [J]. Nature, 1987,327(6120):298-303.

[5] Jen J, Powell SM, Papadopoulos N, et al. Molecular determinants of dysplasia in colorectal lesions [J]. Cancer Res, 1994,54(21):5523-5526

[6] Kern SE, Fearon ER, Tersmette KW, et al. Clinical and pathological associations with allelic loss in colorectal carcinoma [corrected] [J]. JAMA, 1989,261(21):3099-3103.

[7] Jiricny J, Nystrom-Lahti M. Mismatch repair defects in cancer [J]. Curr Opin Genet Dev, 2000,10(2):157-161.

[8] Aaltonen LA, Peltomaki P, Mecklin JP, et al. Replication errors in benign and malignant tumors from hereditary nonpolyposis colorectal cancer patients [J]. Cancer Res, 1994,54(7):16451648 .

[9] Jacoby RF, Marshall DJ, Kailas S, et al. Genetic instability associated with adenoma to carcinoma progression in hereditary nonpolyposis colon cancer [J]. Gastroenterology, 1995, 109(1):73-82.

[10] Bomme L, Bardi G, Pandis N, et al. Cytogenetic analysis of colorectal adenomas: Karyotypic comparisons of synchronous tumors [J]. Cancer Genet Cytogenet, 1998,106(1):66-71.

[11] Ried T, Heselmeyer-Haddad K, Blegen $H$, et al. Genomic changes defining the genesis, progression, and malignancy potential in solid human tumors: a phenotype/genotype correlation [J]. Genes Chromosomes Cancer, 1999,25(3):195204.

[12] Rooney PH, Murray GI, Stevenson DA, et al. Comparative genomic hybridization and chromosomal instability in solid tumours [J]. Br J Cancer, 1999,80(5-6):862-873.

[13] Groden J, Thliveris A, Samowitz W, et al. Identification and characterization of the familial adenomatous polyposis coli gene [J]. Cell, 1991,66(3):589-600.

[14] Kinzler KW, Nilbert MC, Vogelstein B, et al. Identification of a gene located at chromosome $5 \mathrm{q} 21$ that is mutated in colorectal cancers [J]. Science, 1991,251(4999): 1366-1370.

[15] Polakis P. The oncogenic activation of beta-catenin [J]. Curr Opin Genet Dev, 1999,9(1):15-21. better and more rapid understanding of its etiology and providing new opportunities for developing and rapidly testing novel therapies.

\section{Acknowledgements}

This study was sponsored by the $\mathrm{NIH} / \mathrm{NCl}$ grant K99CA138914 (YT), CA112081 (WY), R01CA02603831 and an $A^{*} S T A R$ Investigator Grant (HPK).

Received: 2011-02-09; accepted: 2011-02-18.
[16] McCart AE, Vickaryous NK, Silver A. Apc mice: models, modifiers and mutants [J]. Pathol Res Pract, 2008,204(7):479490.

[17] Korinek V, Barker N, Morin PJ, et al. Constitutive transcriptional activation by a beta-catenin-tcf complex in apc-/- colon carcinoma [J]. Science, 1997,275(5307):1784-1787.

[18] Oshima H, Oshima M, Kobayashi M, et al. Morphological and molecular processes of polyp formation in apc (delta716) knockout mice [J]. Cancer Res, 1997,57(9):1644-1649.

[19] Moser AR, Pitot HC, Dove WF. A dominant mutation that predisposes to multiple intestinal neoplasia in the mouse [J]. Science, 1990,247(4940):322-324.

[20] Su LK, Kinzler KW, Vogelstein B, et al. Multiple intestinal neoplasia caused by a mutation in the murine homolog of the apc gene [J]. Science, 1992,256(5057):668-670.

[21] Halberg RB, Katzung DS, Hoff PD, et al. Tumorigenesis in the multiple intestinal neoplasia mouse: redundancy of negative regulators and specificity of modifiers [J]. Proc Natl Acad Sci U S A, 2000,97(7):3461-3466.

[22] Oshima $M$, Oshima $H$, Kitagawa $K$, et al. Loss of apc heterozygosity and abnormal tissue building in nascent intestinal polyps in mice carrying a truncated apc gene [J] Proc Natl Acad Sci U S A, 1995,92(10):4482-4486.

[23] Pretlow TP, Edelmann W, Kucherlapati R, et al. Spontaneous aberrant crypt foci in apc1638n mice with a mutant apc allele [J]. Am J Pathol, 2003,163(5): 1757-1763.

[24] Colnot S, Niwa-Kawakita M, Hamard G, et al. Colorectal cancers in a new mouse model of familial adenomatous polyposis: influence of genetic and environmental modifiers [J]. Lab Invest, 2004,84(12):1619-1630.

[25] Quesada CF, Kimata H, Mori M, et al. Piroxicam and acarbose as chemopreventive agents for spontaneous intestinal adenomas in apc gene 1309 knockout mice [J]. Jpn J Cancer Res, 1998,89(4):392-396.

[26] Kuraguchi M, Wang XP, Bronson RT, et al. Adenomatous polyposis coli (apc) is required for normal development of skin and thymus [J]. PLoS Genet, 2006,2(9):e146.

[27] Sasai H, Masaki M, Wakitani K. Suppression of polypogenesis in a new mouse strain with a truncated apc (delta474) by a novel cox-2 inhibitor, jte-522 [J]. Carcinogenesis, 2000,21(5): 953-958.

[28] Coletta PL, Muller AM, Jones EA, et al. Lymphodepletion in the apcmin/+ mouse model of intestinal tumorigenesis [J]. Blood, 2004,103(3): 1050-1058. 
[29] Benhamouche S, Decaens T, Godard C, et al. Apc tumor suppressor gene is the "zonation-keeper" of mouse liver [J]. Dev Cell, 2006,10(6):759-770.

[30] Baltgalvis KA, Berger FG, Pena MM, et al. Interleukin-6 and cachexia in apcmin/+ mice [J]. Am J Physiol Regul Integr Comp Physiol, 2008,294(2):R393-401.

[31] Haigis KM, Kendall KR, Wang $Y$, et al. Differential effects of oncogenic k-ras and n-ras on proliferation, differentiation and tumor progression in the colon [J]. Nat Genet, 2008,40 (5): 600-608.

[32] Hung KE, Maricevich MA, Richard LG, et al. Development of a mouse model for sporadic and metastatic colon tumors and its use in assessing drug treatment [J]. Proc Natl Acad Sci U S A, 2010,107(4): 1565-1570

[33] Oshima M, Dinchuk JE, Kargman SL, et al. Suppression of intestinal polyposis in apc delta716 knockout mice by inhibition of cyclooxygenase 2 (cox-2) [J]. Cell, 1996,87(5):803-809.

[34] Oshima M, Murai N, Kargman S, et al. Chemoprevention of intestinal polyposis in the apcdelta716 mouse by rofecoxib, a specific cyclooxygenase-2 inhibitor [J]. Cancer Res, 2001,61 (4): 1733-1740.

[35] Aoki K, Tamai Y, Horiike S, et al. Colonic polyposis caused by mtor-mediated chromosomal instability in apc+/delta716 cdx2+/compound mutant mice [J]. Nat Genet, 2003,35(4):323-330.

[36] Rao CV, Yang YM, Swamy MV, et al. Colonic tumorigenesis in bubr1+/-apcmin/+ compound mutant mice is linked to premature separation of sister chromatids and enhanced genomic instability [J]. Proc Natl Acad Sci U S A, 2005,102 (12):4365-4370

[37] Takaku K, Oshima M, Miyoshi H, et al. Intestinal tumorigenesis in compound mutant mice of both dpc4 (smad4) and apc genes [J]. Cell, 1998,92(5):645-656.

[38] Munoz NM, Upton M, Rojas A, et al. Transforming growth factor beta receptor type ii inactivation induces the malignant transformation of intestinal neoplasms initiated by apc mutation [J]. Cancer Res, 2006,66(20):9837-9844.

[39] Yang WC, Mathew J, Velcich A, et al. Targeted inactivation of the p21 (waf1/cip1) gene enhances apc-initiated tumor formation and the tumor-promoting activity of a western-style high-risk diet by altering cell maturation in the intestinal mucosal [J]. Cancer Res, 2001,61(2):565-569.

[40] Yang W, Velcich A, Lozonschi I, et al. Inactivation of p21waf1/ cip1 enhances intestinal tumor formation in muc2-/- mice [J]. Am J Pathol, 2005,166(4):1239-1246.

[41] Shao J, Washington MK, Saxena R, et al. Heterozygous disruption of the pten promotes intestinal neoplasia in apcmin/+ mouse: roles of osteopontin [J]. Carcinogenesis, 2007,28(12): 2476-2483.

[42] Petrova TV, Nykanen A, Norrmen C, et al. Transcription factor prox1 induces colon cancer progression by promoting the transition from benign to highly dysplastic phenotype [J]. Cancer Cell, 2008,13(5):407-419.

[43] Lynch HT, Smyrk T. Hereditary nonpolyposis colorectal cancer (lynch syndrome). An updated review [J]. Cancer, 1996,78(6): 1149-1167.

[44] Peltomaki P. Role of DNA mismatch repair defects in the pathogenesis of human cancer [J]. J Clin Oncol, 2003,21(6): 1174-1179.

[45] Vasen HF, Boland CR. Progress in genetic testing, classification, and identification of lynch syndrome [J]. JAMA, 2005,293(16):2028-2030.

[46] Rustgi AK. The genetics of hereditary colon cancer [J]. Genes Dev, 2007,21(20):2525-2538.
[47] Aaltonen LA, Peltomaki P, Leach FS, et al. Clues to the pathogenesis of familial colorectal cancer [J]. Science, 1993,260(5109):812-816.

[48] Ionov $Y$, Peinado MA, Malkhosyan S, et al. Ubiquitous somatic mutations in simple repeated sequences reveal a new mechanism for colonic carcinogenesis [J]. Nature, 1993,363 (6429):558-561

[49] Umar A. Lynch syndrome (hnpcc) and microsatellite instability [J]. Dis Markers, 2004,20(4-5):179-180.

[50] Edelmann L, Edelmann W. Loss of DNA mismatch repair function and cancer predisposition in the mouse: animal models for human hereditary nonpolyposis colorectal cancer [J]. Am J Med Genet C Semin Med Genet, 2004,129C(1):9199.

[51] Felton KE, Gilchrist DM, Andrew SE. Constitutive deficiency in DNA mismatch repair [J]. Clin Genet, 2007,71(6):483-498.

[52] de Wind $N$, Dekker $M$, Berns $A$, et al. Inactivation of the mouse msh2 gene results in mismatch repair deficiency, methylation tolerance, hyperrecombination, and predisposition to cancer [J]. Cell, 1995,82(2):321-330.

[53] Reitmair AH, Redston M, Cai JC, et al. Spontaneous intestinal carcinomas and skin neoplasms in msh2-deficient mice [J] Cancer Res, 1996,56(16):3842-3849.

[54] Taketo MM, Edelmann W. Mouse models of colon cancer [J]. Gastroenterology, 2009,136(3):780-798.

[55] Edelmann W, Yang K, Umar A, et al. Mutation in the mismatch repair gene msh6 causes cancer susceptibility [J]. Cell, 1997,91(4):467-477.

[56] Kolodner RD, Tytell JD, Schmeits JL, et al. Germ-line msh6 mutations in colorectal cancer families [J]. Cancer Res, 1999,59(20):5068-5074.

[57] Wijnen J, de Leeuw $W$, Vasen $H$, et al. Familial endometrial cancer in female carriers of msh6 germline mutations [J]. Nat Genet, 1999,23(2): 142-144.

[58] Baker SM, Plug AW, Prolla TA, et al. Involvement of mouse mlh1 in DNA mismatch repair and meiotic crossing over [J] Nat Genet, 1996,13(3):336-342.

[59] Edelmann W, Cohen PE, Kane M, et al. Meiotic pachytene arrest in mlh1-deficient mice [J]. Cell, 1996,85(7):1125-1134.

[60] Prolla TA, Baker SM, Harris AC, et al. Tumour susceptibility and spontaneous mutation in mice deficient in mlh1, pms1 and pms2 DNA mismatch repair [J]. Nat Genet, 1998,18 (3):276279.

[61] Edelmann W, Yang K, Kuraguchi M, et al. Tumorigenesis in mlh1 and mlh1/apc1638n mutant mice [J]. Cancer Res, 1999,59(6): 1301-1307

[62] Reitmair AH, Cai JC, Bjerknes M, et al. Msh2 deficiency contributes to accelerated apc-mediated intestinal tumorigenesis [J]. Cancer Res, 1996,56(13):2922-2926.

[63] Baker SM, Harris AC, Tsao JL, et al. Enhanced intestinal adenomatous polyp formation in pms2-/-;min mice [J]. Cancer Res, 1998,58(6):1087-1089.

[64] Kuraguchi M, Yang K, Wong E, et al. The distinct spectra of tumor-associated apc mutations in mismatch repair-deficient apc1638n mice define the roles of msh3 and msh6 in DNA repair and intestinal tumorigenesis [J]. Cancer Res, 2001,61 (21):7934-7942

[65] Laqueur GL, Mickelsen O, Whiting MG, et al. Carcinogenic properties of nuts from cycas circinalis I. Indigenous to guam [J]. J Natl Cancer Inst, 1963,31:919-951.

[66] Laqueur GL. Carcinogenic effects of cycad meal and cycasin, methylazoxymethanol glycoside, in rats and effects of cycasin in germfree rats [J]. Fed Proc, 1964,23:1386-1388. 
[67] Fiala ES. Investigations into the metabolism and mode of action of the colon carcinogens 1,2-dimethylhydrazine and azoxymethane [J]. Cancer, 1977,40(5 Suppl):2436-2445.

[68] Fiala ES, Joseph C, Sohn OS, et al. Mechanism of benzylselenocyanate inhibition of azoxymethane-induced colon carcinogenesis in $\mathrm{f344}$ rats [J]. Cancer Res, 1991,51(11): 2826-2830.

[69] Weisburger JH. Colon carcinogens: their metabolism and mode of action [J]. Cancer, 1971,28(1):60-70.

[70] Fiala ES, Caswell N, Sohn OS, et al. Non-alcohol dehydrogenase-mediated metabolism of methylazoxymethanol in the deer mouse, peromyscus maniculatus [J]. Cancer Res, 1984,44(7):2885-2891.

[71] Fiala ES, Kulakis C, Christiansen G, et al. Inhibition of the metabolism of the colon carcinogen, azoxymethane, by pyrazole [J]. Cancer Res, 1978,38(12):4515-4521.

[72] Haase P, Cowen DM, Knowles JC. Histogenesis of colonic tumours in mice induced by dimethyl hydrazine [J]. J Pathol, 1973, 109(1):Px.

[73] Martin MS, Martin F, Michiels R, et al. An experimental model for cancer of the colon and rectum. Intestinal carcinoma induced in the rat 1,2-dimethylhydrazine [J]. Digestion, 1973,8 (1):22-34.

[74] Ward JM. Morphogenesis of chemically induced neoplasms of the colon and small intestine in rats [J]. Lab Invest, 1974,30 (4):505-513

[75] Neufert C, Becker C, Neurath MF. An inducible mouse model of colon carcinogenesis for the analysis of sporadic and inflammation-driven tumor progression [J]. Nat Protoc, 2007,2 (8): 1998-2004.

[76] Delker DA, Wang QS, Papanikolaou A, et al. Quantitative assessment of azoxymethane-induced aberrant crypt foci in inbred mice [J]. Exp Mol Pathol, 1999,65(3):141-149.

[77] Nambiar PR, Girnun G, Lillo NA, et al. Preliminary analysis of azoxymethane induced colon tumors in inbred mice commonly used as transgenic/knockout progenitors [J]. Int J Oncol, 2003,22(1):145-150.

[78] Boffa LC, Diwan BA, Gruss R, et al. Differences in colonic nuclear proteins of two mouse strains with different susceptibilities to 1, 2-dimethylhydrazine-induced carcinogenesis [J]. Cancer Res, 1980,40(6): 1774-1780.

[79] Deschner EE, Long FC, Hakissian M. Susceptibility to 1,2dimethylhydrazine-induced colonic tumors and epithelial cell proliferation characteristics of $\mathrm{f} 1$, $\mathrm{f} 2$, and reciprocal backcrosses derived from swr/j and akr/j parental mouse strains [J]. Cancer, 1988,61(3):478-482.

[80] Diwan BA, Dempster AM, Blackman KE. Effects of methylazoxymethanol acetate on inbred mice: influence of genetic factors on tumor induction [J]. Proc Soc Exp Biol Med, 1979, 161(3):347-349.

[81] Evans JT, Shows TB, Sproul EE, et al. Genetics of colon carcinogenesis in mice treated with 1,2-dimethylhydrazine [J]. Cancer Res, 1977,37(1):134-136.

[82] Rosenberg DW, Liu Y. Induction of aberrant crypts in murine colon with varying sensitivity to colon carcinogenesis [J]. Cancer Lett, 1995, 92(2):209-214.

[83] Papanikolaou A, Wang QS, Papanikolaou D, et al. Sequential and morphological analyses of aberrant crypt foci formation in mice of differing susceptibility to azoxymethane-induced colon carcinogenesis [J]. Carcinogenesis, 2000,21(8):1567-1572.

[84] Papanikolaou A, Shank RC, Delker DA, et al. Initial levels of azoxymethane-induced DNA methyl adducts are not predictive of tumor susceptibility in inbred mice [J]. Toxicol Appl
Pharmacol, 1998,150(1):196-203

[85] Nagao M, Honda M, Seino $Y$, et al. Mutagenicities of smoke condensates and the charred surface of fish and meat [J]. Cancer Lett, 1977,2(4-5):221-226.

[86] Sugimura T, Wakabayashi K, Nakagama $\mathrm{H}$, et al. Heterocyclic amines: mutagens/carcinogens produced during cooking of meat and fish [J]. Cancer Sci, 2004,95(4):290-299.

[87] Jagerstad M, Reutersward AL, Grivas S, et al. Effects of meat composition and cooking conditions on the formation of mutagenic imidazoquinoxalines (meiqx and its methyl derivatives) [J]. Princess Takamatsu Symp, 1985, 16(87-96.

[88] Kato R. Metabolic activation of mutagenic heterocyclic aromatic amines from protein pyrolysates [J]. Crit Rev Toxicol, 1986,16 (4):307-348.

[89] Schut HA, Putman KL, Randerath K. DNA adduct formation of the carcinogen 2-amino-3-methylimidazo [4,5-f]-quinoline in target tissues of the $\mathrm{f}-344$ rat [J]. Cancer Lett, 1988,41(3): 345-352.

[90] Tanaka T, Barnes WS, Williams GM, et al. Multipotential carcinogenicity of the fried food mutagen 2-amino-3methylimidazo [4,5-f]quinoline in rats [J]. Jpn J Cancer Res, 1985,76(7):570-576.

[91] Andreassen A, Vikse R, Mikalsen A, et al. 2-amino-1-methyl-6phenylimidazo [4,5-b]pyridine (phip) induces genetic changes in murine intestinal tumours and cells with apcmin mutation [J]. Mutat Res, 2006,604(1-2):60-70.

[92] Andreassen A, Mollersen L, Vikse R, et al. One dose of 2amino-1-methyl-6-phenylimidazo [4,5-b]pyridine (phip) or 2amino-3-methylimidazo [4,5-f] quinoline (iq) induces tumours in $\mathrm{min} /+$ mice by truncation mutations or loh in the apc gene $[\mathrm{J}]$ Mutat Res, 2002,517(1-2):157-166.

[93] Nakagama H, Nakanishi M, Ochiai M. Modeling human colon cancer in rodents using a food-borne carcinogen, phip [J] Cancer Sci, 2005,96(10):627-636.

[94] Shirai T, Sano M, Tamano S, et al. The prostate: a target for carcinogenicity of 2-amino-1-methyl-6-phenylimidazo [4,5-b] pyridine (phip) derived from cooked foods [J]. Cancer Res, 1997,57(2): 195-198.

[95] Ito N, Hasegawa R, Imaida $K$, et al. Carcinogenicity of 2amino-1-methyl-6-phenylimidazo [4,5-b]pyridine (phip) in the rat [J]. Mutat Res, 1997,376(1-2):107-114.

[96] Chen C, Ma X, Malfatti MA, et al. A comprehensive investigation of 2-amino-1-methyl-6-phenylimidazo [4,5-b] pyridine (phip) metabolism in the mouse using a multivariate data analysis approach [J]. Chem Res Toxicol, 2007,20 (3): 531-542.

[97] Reddy BS, Rivenson A. Inhibitory effect of bifidobacterium longum on colon, mammary, and liver carcinogenesis induced by 2-amino-3-methylimidazo [4,5-f]quinoline, a food mutagen [J]. Cancer Res, 1993,53(17):3914-3918.

[98] Walpole AL, Williams MH, Roberts DC. The carcinogenic action of 4-aminodiphenyl and 3:2'-dimethyl-4-amino-diphenyl [J]. $\mathrm{Br}$ $\mathrm{J}$ Ind Med, 1952,9(4):255-263.

[99] Reddy BS, Ohmori T. Effect of intestinal microflora and dietary fat on 3,2'-dimethyl-4-aminobiphenyl-induced colon carcinogenesis in 1344 rats [J]. Cancer Res, 1981,41(4):1363-1367.

[100] Spjut HJ, Noall MW. Experimental induction of tumors of the large bowel of rats. A review of the experience with 3-2 dimethyl-4-aminobiphenyl [J]. Cancer, 1971,28(1):29-37.

[101] Decaens C, Gautier R, Daher N, et al. Induction of rat intestinal carcinogenesis with single doses, low and high repeated doses of 1,2-dimethylhydrazine [J]. Carcinogenesis, $1989,10(1): 69-72$. 
[102] Ward JM. Dose response to a single injection of azoxymethane in rats. Induction of tumors in the gastrointestinal tract, auditory sebaceous glands, kidney, liver and preputial gland [J]. Vet Pathol, 1975, 12(3): 165-177.

[103] Narisawa T, Magadia NE, Weisburger JH, et al. Promoting effect of bile acids on colon carcinogenesis after intrarectal instillation of n-methyl-n'-nitro-n-nitrosoguanidine in rats [J]. J Natl Cancer Inst, 1974,53(4):1093-1097.

[104] Narisawa T, Weisburger JH. Colon cancer induction in mice by intrarectal instillation of $n$-methylnitosorurea (38498) [J]. Proc Soc Exp Biol Med, 1975,148(1):166-169.

[105] Narisawa T, Sato T, Hayakawa M, et al. Carcinoma of the colon and rectum of rats by rectal infusion of n-methyl-n'-nitron-nitrosoguanidine [J]. Gann, 1971,62(3):231-234.

[106] Reddy BS, Narisawa T, Maronpot R, et al. Animal models for the study of dietary factors and cancer of the large bowel [J]. Cancer Res, 1975,35(11 Pt. 2):3421-3426.

[107] Jacoby RF, Llor X, Teng BB, et al. Mutations in the k-ras oncogene induced by 1,2-dimethylhydrazine in preneoplastic and neoplastic rat colonic mucosa [J]. J Clin Invest, 1991,87 (2):624-630

[108] Jacoby RF, Alexander RJ, Raicht RF, et al. K-ras oncogene mutations in rat colon tumors induced by $n$-methyl-nnitrosourea [J]. Carcinogenesis, 1992,13(1):45-49.

[109] Bolt AB, Papanikolaou A, Delker DA, et al. Azoxymethane induces ki-ras activation in the tumor resistant akr/j mouse colon [J]. Mol Carcinog, 2000,27(3):210-218.

[110] De Filippo C, Caderni G, Bazzicalupo M, et al. Mutations of the apc gene in experimental colorectal carcinogenesis induced by azoxymethane in $\mathrm{f} 344$ rats $[\mathrm{J}]$. $\mathrm{Br} \mathrm{J}$ Cancer, 1998,77(12):2148-2151.

[111] Erdman SH, Wu HD, Hixson LJ, et al. Assessment of mutations in ki-ras and p53 in colon cancers from azoxymethane- and dimethylhydrazine-treated rats [J]. Mol Carcinog, 1997,19(2): $137-144$.

[112] Kakiuchi H, Watanabe M, Ushijima T, et al. Specific 5'-ggga-3' $\rightarrow 5^{\prime}$-gga- $3^{\prime}$ mutation of the apc gene in rat colon tumors induced by 2-amino-1-methyl-6-phenylimidazo [4,5-b]pyridine [J]. Proc Natl Acad Sci U S A, 1995,92(3):910-914.

[113] Matsumoto K, Iwase T, Hirono I, et al. Demonstration of ras and p53 gene mutations in carcinomas in the forestomach and intestine and soft tissue sarcomas induced by n-methyl-nnitrosourea in the rat [J]. Jpn J Cancer Res, 1997,88(2):129136.

[114] Kakiuchi $H$, Ushijima $T$, Ochiai $M$, et al. Rare frequency of activation of the ki-ras gene in rat colon tumors induced by heterocyclic amines: possible alternative mechanisms of human colon carcinogenesis [J]. Mol Carcinog, 1993,8(1):44-48.

[115] Dashwood $\mathrm{RH}$, Suzui M, Nakagama $\mathrm{H}$, et al. High frequency of beta-catenin (ctnnb1) mutations in the colon tumors induced by two heterocyclic amines in the $\mathrm{f344}$ rat [J]. Cancer Res, 1998,58(6): 1127-1129.

[116] Blum CA, Tanaka T, Zhong $X$, et al. Mutational analysis of ctnnb1 and apc in tumors from rats given 1,2dimethylhydrazine or 2-amino-3-methylimidazo [4,5-f]quinoline: mutational "hotspots" and the relative expression of betacatenin and C-jun [J]. Mol Carcinog, 2003,36(4):195-203.

[117] Takahashi M, Nakatsugi S, Sugimura T, et al. Frequent mutations of the beta-catenin gene in mouse colon tumors induced by azoxymethane [J]. Carcinogenesis, 2000,21 (6): $1117-1120$.

[118] Okayasu I, Hatakeyama S, Yamada M, et al. A novel method in the induction of reliable experimental acute and chronic ulcerative colitis in mice [J]. Gastroenterology, 1990,98(3):694702

[119] Seril DN, Liao J, Yang GY, et al. Oxidative stress and ulcerative colitis-associated carcinogenesis: studies in humans and animal models [J]. Carcinogenesis, 2003,24(3):353-362.

[120] Suzuki R, Kohno H, Sugie S, et al. Strain differences in the susceptibility to azoxymethane and dextran sodium sulfateinduced colon carcinogenesis in mice [J]. Carcinogenesis, 2006,27(1):162-169.

[121] Okayasu I, Yamada M, Mikami T, et al. Dysplasia and carcinoma development in a repeated dextran sulfate sodiuminduced colitis model [J]. J Gastroenterol Hepatol, 2002,17 (10): 1078-1083.

[122] Tanaka T, Kohno $H$, Suzuki R, et al. A novel inflammationrelated mouse colon carcinogenesis model induced by azoxymethane and dextran sodium sulfate [J]. Cancer Sci, 2003,94(11):965-973

[123] Tanaka T, Suzuki R, Kohno H, et al. Colonic adenocarcinomas rapidly induced by the combined treatment with 2-amino-1methyl-6-phenylimidazo [4,5-b]pyridine and dextran sodium sulfate in male icr mice possess beta-catenin gene mutations and increases immunoreactivity for beta-catenin, cyclooxygenase-2 and inducible nitric oxide synthase [J]. Carcinogenesis, 2005,26(1):229-238.

[124] Kohno H, Suzuki R, Sugie S, et al. Beta-catenin mutations in a mouse model of inflammation-related colon carcinogenesis induced by 1,2-dimethylhydrazine and dextran sodium sulfate [J]. Cancer Sci, 2005,96(2):69-76.

[125] Koesters R, Hans MA, Benner A, et al. Predominant mutation of codon 41 of the beta-catenin proto-oncogene in rat colon tumors induced by 1,2-dimethylhydrazine using a complete carcinogenic protocol [J]. Carcinogenesis, 2001,22(11):18851890.

[126] Suzuki R, Miyamoto S, Yasui Y, et al. Global gene expression analysis of the mouse colonic mucosa treated with azoxymethane and dextran sodium sulfate [J]. BMC Cancer, $2007,7: 84$

[127] Cheung C, Loy S, Li GX, et al. Rapid induction of colon carcinogenesis in CYP1A-humanized mice by 2-amino-1methyl-6-phenylimidazo [4,5-b]pyridine and dextran sodium sulfate [J]. Carcinogenesis, 2011,32(2):233-239.

[128] Berg DJ, Davidson N, Kuhn R, et al. Enterocolitis and colon cancer in interleukin-10-deficient mice are associated with aberrant cytokine production and cd4 (+) th1-like responses [J]. J Clin Invest, 1996,98(4):1010-1020.

[129] Simpson SJ, Mizoguchi E, Allen D, et al. Evidence that cd4+, but not $c d 8+t$ cells are responsible for murine interleukin-2deficient colitis [J]. Eur J Immunol, 1995,25(9):2618-2625.

[130] Shah SA, Simpson SJ, Brown LF, et al. Development of colonic adenocarcinomas in a mouse model of ulcerative colitis [J] Inflamm Bowel Dis, 1998,4(3):196-202.

[131] Schultz M, Tonkonogy SL, Sellon RK, et al. II-2-deficient mice raised under germfree conditions develop delayed mild focal intestinal inflammation [J]. Am J Physiol, 1999,276 (6 Pt 1): G1461-1472.

[132] Sellon RK, Tonkonogy S, Schultz M, et al. Resident enteric bacteria are necessary for development of spontaneous colitis and immune system activation in interleukin-10-deficient mice [J]. Infect Immun, 1998,66(11):5224-5231.

[133] Kado S, Uchida K, Funabashi H, et al. Intestinal microflora are necessary for development of spontaneous adenocarcinoma of the large intestine in T-cell receptor beta chain and p53 double-knockout mice [J]. Cancer Res, 2001,61(6):2395-2398. 
[134] Engle SJ, Ormsby I, Pawlowski S, et al. Elimination of colon cancer in germ-free transforming growth factor beta 1-deficient mice [J]. Cancer Res, 2002,62(22):6362-6366.

[135] Greten FR, Eckmann L, Greten TF, et al. Ikkbeta links inflammation and tumorigenesis in a mouse model of colitisassociated cancer [J]. Cell, 2004,118(3):285-296.

[136] Burstein E, Fearon ER. Colitis and cancer: a tale of inflammatory cells and their cytokines [J]. J Clin Invest, 2008,118(2): 464-467.

[137] Kobayashi KS, Chamaillard M, Ogura Y, et al. Nod2dependent regulation of innate and adaptive immunity in the intestinal tract [J]. Science, 2005,307(5710):731-734.

[138] Maeda S, Hsu LC, Liu H, et al. Nod2 mutation in crohn's disease potentiates NF-kappaB activity and IL-1beta processing [J]. Science, 2005,307(5710):734-738.

[139] Fukata M, Chen A, Vamadevan AS, et al. Toll-like receptor-4 promotes the development of colitis-associated colorectal tumors [J]. Gastroenterology, 2007,133(6):1869-1881.

[140] Popivanova BK, Kitamura K, Wu Y, et al. Blocking TNF-alpha in mice reduces colorectal carcinogenesis associated with chronic colitis [J]. J Clin Invest, 2008,118(2):560-570.

[141] Velcich A, Yang W, Heyer J, et al. Colorectal cancer in mice genetically deficient in the mucin muc2 [J]. Science, 2002,295 (5560): 1726-1729.

[142] Velcich A, Palumbo L, Selleri L, et al. Organization and regulatory aspects of the human intestinal mucin gene (muc2) locus [J]. J Biol Chem, 1997,272(12):7968-7976.

[143] van Klinken BJ, Einerhand AW, Duits LA, et al. Gastrointestinal expression and partial cDNA cloning of murine muc2 [J]. Am J Physiol, 1999,276(1 Pt 1):G115-124.

[144] Fodde R, Edelmann W, Yang K, et al. A targeted chaintermination mutation in the mouse apc gene results in multiple intestinal tumors [J]. Proc Natl Acad Sci U S A, 1994,91(19): 8969-8973.

[145] $\mathrm{Bi}$ X, Fang W, Wang LS, et al. Black raspberries inhibit intestinal tumorigenesis in apc1638+/- and muc2 -/- mouse models of colorectal cancer [J]. Cancer Prev Res (Phila), 2010,3(11):1443-1450.

[146] Yang K, Popova NV, Yang WC, et al. Interaction of muc2 and apc on wht signaling and in intestinal tumorigenesis: potential role of chronic inflammation [J]. Cancer Res, 2008,68 (18): 7313-7322.

[147] Segal NH, Saltz LB. Evolving treatment of advanced colon cancer [J]. Annu Rev Med, 2009,60(207-219.

[148] Fidler IJ. Orthotopic implantation of human colon carcinomas into nude mice provides a valuable model for the biology and therapy of metastasis [J]. Cancer Metastasis Rev, 1991,10(3): 229-243.

[149] Goldrosen MH. Murine colon adenocarcinoma: immunobiology of metastases [J]. Cancer, 1980,45(5 Suppl):1223-1228.

[150] Inoue $Y$, Kashima $Y$, Aizawa $K$, et al. A new rat colon cancer cell line metastasizes spontaneously: biologic characteristics and chemotherapeutic response [J]. Jpn J Cancer Res, 1991,82(1):90-97.

[151] Hoffman RM. Orthotopic metastatic (metamouse) models for discovery and development of novel chemotherapy [J]. Methods Mol Med, 2005,111:297-322.

[152] Sun FX, Sasson AR, Jiang $P$, et al. An ultra-metastatic model of human colon cancer in nude mice [J]. Clin Exp Metastasis, $1999,17(1): 41-48$

[153] Kashtan H, Rabau M, Mullen JB, et al. Intra-rectal injection of tumour cells: a novel animal model of rectal cancer [J]. Surg Oncol, 1992,1(3):251-256.
[154] Boni L, Benevento A, Dionigi G, et al. Injection of colorectal cancer cells in mesenteric and antimesenteric sides of the colon results in different patterns of metastatic diffusion: an experimental study in rats [J]. World J Surg Oncol, 2005,3:69.

[155] Cespedes MV, Espina C, Garcia-Cabezas MA, et al. Orthotopic microinjection of human colon cancer cells in nude mice induces tumor foci in all clinically relevant metastatic sites [J]. Am J Pathol, 2007,170(3):1077-1085.

[156] Flatmark K, Maelandsmo GM, Martinsen M, et al. Twelve colorectal cancer cell lines exhibit highly variable growth and metastatic capacities in an orthotopic model in nude mice [J] Eur J Cancer, 2004,40(10):1593-1598.

[157] Giavazzi R, Jessup JM, Campbell DE, et al. Experimental nude mouse model of human colorectal cancer liver metastases [J] J Natl Cancer Inst, 1986,77(6):1303-1308.

[158] Wagner HE, Toth CA, Steele GD, Jr., et al. Metastatic potential of human colon cancer cell lines: relationship to cellular differentiation and carcinoembryonic antigen production [J] Clin Exp Metastasis, 1992,10(1):25-31.

[159] Hamada K, Monnai M, Kawai K, et al. Liver metastasis models of colon cancer for evaluation of drug efficacy using NOD/Shiscid IR2Rgammanull (NOG) mice [J]. Int J Oncol, 2008,32(1): 153-159.

[160] Lafreniere R, Rosenberg SA. A novel approach to the generation and identification of experimental hepatic metastases in a murine model [J]. J Natl Cancer Inst, 1986,76 (2):309-322.

[161] Casillas S, Dietz DW, Brand MI, et al. Perfusion to colorectal cancer liver metastases is not uniform and depends on tumor location and feeding vessel [J]. J Surg Res, 1997,67(2):179185.

[162] Dunnington DJ, Buscarino C, Gennaro D, et al. Characterization of an animal model of metastatic colon carcinoma [J]. Int J Cancer, 1987,39(2):248-254.

[163] Ku Y, Kusunoki N, Shiotani M, et al. Stimulation of haematogenous liver metastases by ischaemia-reperfusion in rats [J]. Eur J Surg, 1999,165(8):801-807.

[164] Doi K, Horiuchi T, Uchinami M, et al. Neutrophil elastase inhibitor reduces hepatic metastases induced by ischaemiareperfusion in rats [J]. Eur J Surg, 2002,168(8-9):507-510.

[165] Ravikumar TS, D’Emilia J, Cocchiaro C, et al. Experimental liver metastasis. Implications of clonal proclivity and organ specificity [J]. Arch Surg, 1989,124(1):49-54.

[166] Hagenaars M, Ensink NG, Basse $\mathrm{PH}$, et al. The microscopic anatomy of experimental rat cc531 colon tumour metastases: consequences for immunotherapy? [J]. Clin Exp Metastasis, 2000,18(2): 189-196.

[167] Thomas C, Nijenhuis AM, Timens W, et al. Liver metastasis model of colon cancer in the rat: immunohistochemical characterization [J]. Invasion Metastasis, 1993,13(2): 102-112.

[168] Mook OR, Van Marle J, Vreeling-Sindelarova $H$, et al. Visualization of early events in tumor formation of egfptransfected rat colon cancer cells in liver [J]. Hepatology, 2003,38(2):295-304.

[169] Rodenbach M, Eyol E, Seelig MH, et al. Combination treatment of CC531-Lac-Z rat liver metastases by chemoembolization with pemetrexed disodium and gemcitabine [J]. J Cancer Res Clin Oncol, 2005,131(5):289-299

[170] Liu DL, Radnell M, Svanberg K, et al. Immunotherapy in liver tumors: III. A new experimental model of metastatic liver tumors from colorectal carcinoma for cytokine therapy [J]. Cancer Lett, 1995,88(2):211-219.

[171] Alves A, Charre L, Panis $Y$, et al. Total vascular exclusion of 
the liver enhances the efficacy of retroviral-mediated associated thymidine kinase and interleukin-2 genes transfer against multiple hepatic tumors in rats [J]. Surgery, 2003,133(6):669677.

[172] Shinozaki K, Ebert O, Woo SL. Treatment of multi-focal colorectal carcinoma metastatic to the liver of immunecompetent and syngeneic rats by hepatic artery infusion of oncolytic vesicular stomatitis virus [J]. Int J Cancer, 2005,114 (4):659-664.

[173] Van Hillegersberg R, Kort WJ, Vermeij M, et al. Treatment of experimental liver metastases with a noncontact neodymium: Yag laser [J]. J Surg Res, 1992,53(2):128-135.

[174] van Duijnhoven FH, Tollenaar RA, Terpstra OT, et al. Locoregional therapies of liver metastases in a rat cc531 coloncarcinoma model results in increased resistance to tumour rechallenge [J]. Clin Exp Metastasis, 2005,22(3):247-253.

[175] Rothbarth J, Woutersen RA, Sparidans RW, et al. Melphalan antitumor efficacy and hepatotoxicity: the effect of variable infusion duration in the hepatic artery [J]. J Pharmacol Exp
Ther, 2003,305(3): 1098-1103.

[176] Carlsson G, Ekelund L, Hafstrom L, et al. Effects of hepatic artery ligation and intraarterial embolization on liver tumor growth --an experimental study in rats [J]. J Surg Oncol, 1981, 17(3):249-261.

[177] Mack P, Jeppsson B, Widlus D, et al. Combined intermittent dearterialization and intraperitoneal 5-fluorouracil administration for liver tumours in the rat [J]. Eur $\mathrm{J}$ Cancer Clin Oncol, 1988,24(5):909-913.

[178] Sturesson C, Liu DL, Stenram U, et al. Hepatic inflow occlusion increases the efficacy of interstitial laser-induced thermotherapy in rat [J]. J Surg Res, 1997,71(1):67-72.

[179] Lechaux D, Gervais A, Dazord L, et al. Adoptive immunotherapy monitored by micro-MRI in experimental colorectal liver metastasis [J]. Anticancer Res, 2002,22(1A): $151-158$.

[180 ] Rashidi B, Gamagami R, Sasson A, et al. An orthotopic mouse model of remetastasis of human colon cancer liver metastasis [J]. Clin Cancer Res, 2000,6(6):2556-2561.
Submit your next manuscript to Chinese Journal of Cancer and take full advantage of:

- Open access

- No charge to authors

- Quickly published

- Thorough peer review

- Professionally edited

- No space constraints

- Indexed by PubMed, CA, and Google Scholar

Submit your manuscript at

www.cjcsysu.com 